\title{
Measurement of AI3, AI4, and DS4 IT Process Maturity Using the Cobit 4.1 Framework at KOMINFO Bantul
}

\author{
Goldi Mahardika Muhammad $^{1}$, Chayadi Oktomy ${ }^{1 *}$ and Aprilia Kurnianti ${ }^{1}$ \\ ${ }^{1}$ Universitas Muhammadiyah Yogyakarta, Jln.Brawijaya, Tamantirto, Kasihan, Bantul, Yogyakarta 55183, \\ Indonesia \\ *Corresponding author: chayadions@ft.umy.ac.id
}

\begin{abstract}
This research discusses the condition of information technology at KOMINFO (DISKOMINFO) Bantul governance. This study aims to discover where has KOMINFO applied information technology governance properly. This research focuses only on IT processes. Only the AI3 IT process discussed how to generate and maintain the IT infrastructure. AI4 IT process discussed how to enable and use the IT infrastructure, and the last is the DS4 IT process that discussed how to ensure sustainable services. A questionnaire, an interview with employees of KOMINFO Bantul, and documentation were utilized to collect data. Data processing results were used to determine the maturity level of information technology governance at KOMINFO Bantul. After knowing the maturity level of the IT processes, then it was analyzed to measure the alignment between the TKTI current condition with the TKTI condition equipped with the COBIT framework.
\end{abstract}

Keywords: Information Technology Governance, COBIT 4.1, DISKOMINFO Bantul.

\section{Introduction}

Indonesia has departments running the state government, the Ministry of Communication and Information Technology (DISKOMINFO). It is a department or ministry within the Indonesian government that assists in managing communication and informatics affairs. DISKOMINFO in Bantul has a strategic plan to realize Bantul Smart (Bantul Smart City) by developing technologybased, integrated, sustainable and environmentally friendly information and communication systems. It is in accordance with smart city application areas in this $21^{\text {st }}$ century that is formulated by Eremia et al. [1]. To achieve this plan, KOMINFO Bantul improves quality and adequate data information services and creates an effective, efficient, transparent and accountable government bureaucracy to improve service excellence and achieve good governance [2]. It also develops technology-based information and communication systems environmentally friendly and competitive. KOMINFO Bantul has implemented information technology governance. However, the extent to which this information technology application process has been carried out is still unknown. Hence, information technology governance used is not yet optimal.

Finally, the authors measured the maturity level of the information technology governance process using the Control Objectives for Information and Related (COBIT) framework to determine the extent to which the information technology process has been carried out. COBIT is the best practice that can help users and management to link the gap between business risks, control needs, and technical problems related to information technology in achieving organizational goals. COBIT has been used by several offices around Indonesia beside Bantul. Government of Bandung Regency used COBIT to make Recommendations for Improving its Data Management Process [3]. Besides that, Ditreskrimsus Polda created IT security Governance Roadmap and recommendations [4], [5]. Furthermore, The secretariat general of the Indonesian house of representatives used COBIT framework to evaluate and make processes improvement prioritization in its IT Governance [6]. Therefore, it is a wise choice to used COBIT in this research. 


\section{Method}

\subsection{Data Collecting}

This research is a quantitative study. The data were obtained in the form of information from sources regarding the implementation of information technology governance at KOMINFO Bantul. This data collection was used to measure the maturity level of information technology process control at KOMINFO Bantul to achieve organizational goals based on the COBIT 4.1 framework. This process was carried out by looking at the vision and mission of KOMINFO Bantul on the website https://diskominfo.bantulkab.go.id.

\subsection{Selection of Information Technology Process}

In this process, the authors selected the information technology process based on the vision and mission of KOMINFO Bantul. The selection was adjusted to the information technology process in the COBIT framework. The IT process selection flow is presented in the following figure.

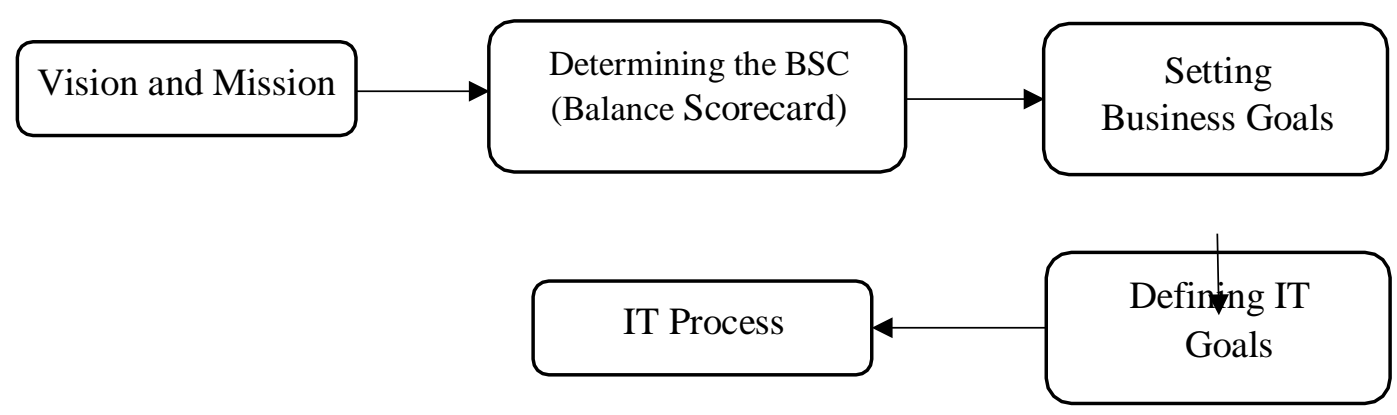

Figure 1. IT Process Selection Flow

\subsection{Determining the Priority Scale of Information Technology}

This process aimed out to meet the needs. The selection of priority scales was based on a questionnaire given to staff at KOMINFO Bantul. The priority questionnaire contained the information technology process of KOMINFO Bantul and was given a scale from the most needed to the one not needed. After processing priority scale data, three IT processes were measured and become the top priority in this research.

\subsection{Establishing A Maturity Level Questionnaire}

In this process, the authors proposed a questionnaire in a language easy to understand. The questionnaire in this study was used to determine the maturity level of information technology management used at KOMINFO Bantul by looking at users' responses and decision making in implementing technology. The assessment has a value level on a scale of 0 to 5 . The respondents chosen represented the responsibility, accountability, consult, and inform (RACI) table in data processing [7]. The questionnaire was based on the maturity model, Critical Success Factor (CSF), and Key Performance Indicator (KPI).

\subsection{Filling the Questionnaire by Respondents}

The writers provided a questionnaire for respondents previously determined based on the RACI table. In filling out the questionnaire, respondents were allowed to ask questions if necessary. The writers were responsible for explaining to the respondents to avoid misunderstanding between them. Therefore, the data obtained were accurate.

\subsection{Questionnaire Data Processing}

The authors processed the data obtained from the questionnaires filled by the respondents by checking the completeness, the meaning clarity, and the suitability of the answers. The authors then 
analyzed the current maturity level using the Excel 2013 computerized system. The method of measuring maturity level and level of gap used the level of compliance method [8].

\subsection{Current Maturity Level}

The writers determined the maturity level at KOMINFO Bantul based on the questionnaire data processing in the previous stage. The results were then adjusted for each IT process used as a questionnaire. The predetermined results were the current state of maturity level at KOMINFO Bantul.

\subsection{Recommendation}

Recommendations for improvement were obtained from the analysis results on the current maturity level and the expected maturity level. By knowing the maturity level of information technology, the writers then adjusted to the maturity level, CSF, and KPI in each information technology process. The writers provided recommendations to KOMINFO Bantul on how to improve it.

\section{Results}

\subsection{Test Results}

a. Questionnaire Data Analysis of the AI3 IT Process Maturity Level

Table 1. Questionnaire Results of the AI3 IT Process Maturity Level

\begin{tabular}{|c|c|c|c|c|c|}
\hline $\begin{array}{l}\text { Maturity } \\
\text { Level } \\
\text { (ML) }\end{array}$ & $\begin{array}{c}\text { Sum of } \\
\text { Statements } \\
\text { Compliance } \\
\text { Value (A) }\end{array}$ & $\begin{array}{c}\text { Sum of } \\
\text { Statements } \\
\text { Compliance } \\
\text { Value (B) }\end{array}$ & $\begin{array}{c}\text { Not } \\
\text { Normalized } \\
\text { Compliance } \\
\text { Value } \\
(\mathbf{C}=\mathbf{A} / \mathbf{B})\end{array}$ & $\begin{array}{c}\text { Normalized } \\
\text { Compliance } \\
\text { Value }(\mathbf{D}=\mathbf{C} / \\
\left.\sum \mathbf{C}\right)\end{array}$ & $\begin{array}{c}\text { Contribu } \\
\text { tion } \\
\text { (MLxD) }\end{array}$ \\
\hline 0 & 0.66 & 1.00 & 0.66 & 0.16 & 0.00 \\
\hline 1 & 1.65 & 4.00 & 0.41 & 0.10 & 0.10 \\
\hline 2 & 3.32 & 5.00 & 0.66 & 0.16 & 0.33 \\
\hline 3 & 3.32 & 4.00 & 0.83 & 0.20 & 0.61 \\
\hline 4 & 3.32 & 4.00 & 0.83 & 0.20 & 0.82 \\
\hline \multirow[t]{2}{*}{5} & 3.30 & 5.00 & 0.66 & 0.16 & 0.81 \\
\hline & & Total $\sum \mathbf{C}$ & 4.06 & $\begin{array}{c}\text { Maturity } \\
\text { Value }\end{array}$ & 2.67 \\
\hline
\end{tabular}

Table 1 presents the questionnaire results from one of the respondents. In the first row, the maturity level 0 column Sum of Statements Compliance Value, denoted by A, has a value of 0.66. This value was obtained from the total value of the questionnaire at the maturity level 0 . The Sum of Statements Compliance Value column, marked with B, is the number of questions at maturity level 0 , resulting in 1.00. The Not Normalize Compliance Value column, denoted by $\mathrm{C}$, is the quotient of value A with value $B$, resulting in 0.66 for maturity level 0 . The Normalize Compliance Value column, denoted by $\mathrm{D}$, is the division of column $\mathrm{C}$ by the number of $\mathrm{C}$. The number $\mathrm{C}$ results from the sum of $\mathrm{C}$ from maturity level 0 to level 5 , and yields 4.06 . Thus, dividing the value of $\mathrm{C}$ by the total number of $\mathrm{C}$ results in 0.16 . The Contribution column is the result of multiplying the maturity level (ML) with the Normalize Contribution Value (D), where at maturity level 0 , the value is 0.00 . The final result of the maturity level is the sum of the contribution maturity level 0 to level 5 , with a value of 2.67 .

The AI3 IT process has six respondents producing different maturity levels. Below is the final result of the maturity level values of the six respondents: 
Table 2. The Average Value of AI3 IT Process Maturity Level

\begin{tabular}{cc}
\hline Respondent & Maturity Level \\
\hline 1 & 2.51 \\
2 & 2.63 \\
3 & 2.37 \\
4 & 2.47 \\
5 & 3.20 \\
6 & 2.67 \\
Average ( $\sum$ ML/6) & $\mathbf{2 . 6 4}$ \\
\hline
\end{tabular}

The table above displays the maturity level of each respondent. The average of the six respondents was sought to obtain the final maturity level. The maturity level of the AI3 IT process is 2.64. Thus, it is at level 3 (defined process).

1) Questionnaire Data Analysis of the AI4 IT Process Maturity Level

Table 3. Questionnaire Results of the AI4 IT Process Maturity Level

\begin{tabular}{cccccc}
\hline $\begin{array}{c}\text { Maturity } \\
\text { Level } \\
\text { (ML) }\end{array}$ & $\begin{array}{c}\text { Sum of } \\
\text { Statements } \\
\text { Compliance } \\
\text { Value (A) }\end{array}$ & $\begin{array}{c}\text { Sum of } \\
\text { Statements } \\
\text { Compliance } \\
\text { Value (B) }\end{array}$ & $\begin{array}{c}\text { Not } \\
\text { Normalized } \\
\text { Compliance } \\
\text { Value } \\
(\mathbf{C = A}=\mathbf{B})\end{array}$ & $\begin{array}{c}\text { Normalized } \\
\text { Compliance } \\
\text { Value (D=C / } \\
\text { (C) }\end{array}$ & $\begin{array}{c}\text { Contribu } \\
\text { tion } \\
\text { (MLxD) }\end{array}$ \\
\hline 0 & 1.66 & 2.00 & 1.20 & 0.16 & 0.00 \\
1 & 3.96 & 6.00 & 1.52 & 0.20 & 0.20 \\
2 & 3.98 & 5.00 & 1.26 & 0.16 & 0.33 \\
3 & 7.30 & 9.00 & 1.23 & 0.16 & 0.49 \\
4 & 4.98 & 6.00 & 1.20 & 0.16 & 0.63 \\
5 & 3.32 & 4.00 & 1.20 & 0.16 & 0.79 \\
& & Total $\sum \mathbf{C}$ & $\mathbf{7 . 6 2}$ & Maturity & $\mathbf{2 . 4 4}$ \\
& & & & Value & \\
\hline
\end{tabular}

Table 3 demonstrates the questionnaire results from the AI4 IT process. At maturity level 0, the Sum of Statements Compliance Value column, denoted by A, has a value of 1.66. This value was obtained from the total value of the questionnaire at the maturity level 0 . The Sum of Statements Compliance Values column, denoted by B, is the number of statements in maturity level 0, resulting in 2.00. The Not Normalize Compliance Value column, denoted by $\mathrm{C}$, is the quotient of value $\mathrm{A}$ with value $\mathrm{B}$ obtaining 1.20 for maturity level 0. The Normalize Compliance Value column, denoted by D, is the division of column $\mathrm{C}$ by the number of $\mathrm{C}$. The amount $\mathrm{C}$ is the result of the sum of $\mathrm{C}$ from maturity level 0 to level 5 and yields 7.62. Dividing the value of $C$ with the total number of $C$ produces a value of 0.16 for maturity level 0 . The Contribution column is the result of multiplying the maturity level (ML) with the Normalize Contribution Value (D), where at maturity level 0 , the value is 0.00 .

The final result of the maturity level is the sum of the contribution maturity level 0 to level 5, obtaining 2.44. In the AI4 IT process, six respondents produce different maturity levels, presented as follows: 
Table 4. The Average Value of the AI4 IT Process Maturity Level

\begin{tabular}{cc}
\hline Respondent & Maturity Level \\
\hline 1 & 2.44 \\
2 & 2.83 \\
3 & 2.54 \\
4 & 2.88 \\
5 & 2.67 \\
6 & 3.03 \\
Average ( $\sum$ ML/6) & $\mathbf{2 . 7 3}$ \\
\hline
\end{tabular}

Table 4 displays the maturity level of each respondent. The average value of the six respondents was calculated to determine the maturity level, obtaining 2.73. Thus, it is at level 3 (defined process).

2) Questionnaire Data Analysis of the DS4 IT Process Maturity Level

Table 5. Questionnaire Results of the DS4 IT Process Maturity Level

\begin{tabular}{|c|c|c|c|c|c|}
\hline $\begin{array}{l}\text { Maturity } \\
\text { Level } \\
\text { (ML) }\end{array}$ & $\begin{array}{c}\text { Sum of } \\
\text { Statements } \\
\text { Compliance } \\
\text { Value (A) }\end{array}$ & $\begin{array}{c}\text { Sum of } \\
\text { Statements } \\
\text { Compliance } \\
\text { Value (B) }\end{array}$ & $\begin{array}{c}\text { Not } \\
\text { Normalized } \\
\text { Compliance } \\
\text { Value } \\
(\mathrm{C}=\mathrm{A} / \mathrm{B})\end{array}$ & $\begin{array}{c}\text { Normalized } \\
\text { Compliance } \\
\text { Value }(\mathbf{D}=\mathbf{C} \\
\left.\quad / \sum \mathbf{C}\right)\end{array}$ & $\begin{array}{c}\text { Contribu } \\
\text { tion } \\
(M L x D)\end{array}$ \\
\hline 0 & 1.32 & 2.00 & 0.66 & 0.19 & 0.00 \\
\hline 1 & 3.30 & 6.00 & 0.55 & 0.16 & 0.16 \\
\hline 2 & 2.64 & 6.00 & 0.44 & 0.13 & 0.25 \\
\hline 3 & 4.95 & 8.00 & 0.62 & 0.18 & 0.53 \\
\hline 4 & 5.61 & 9.00 & 0.62 & 0.18 & 0.72 \\
\hline \multirow[t]{2}{*}{5} & 5.94 & 10.00 & 0.59 & 0.17 & 0.85 \\
\hline & & Total $\sum \mathrm{C}$ & 3.49 & $\begin{array}{c}\text { Maturity } \\
\text { Value }\end{array}$ & 2.51 \\
\hline
\end{tabular}

Table 5 depicts the questionnaire results from the DS4 IT process. At maturity level 0, the Sum of Statements Compliance Value column, denoted by A, has a value of 1.32. This value was obtained from the total value of the questionnaire at the maturity level 0. The Sum of Statements Compliance Values column, denoted by $\mathrm{B}$, is the number of statements in maturity level 0 , producing 2.00. The Not Normalize Compliance Value column, denoted by $\mathrm{C}$, is the quotient of value A with value B obtaining 0.66 for maturity level 0 . The Normalize Compliance Value column, denoted by $\mathrm{D}$, is the division of column $\mathrm{C}$ by the number of $\mathrm{C}$. The number $\mathrm{C}$ results from the sum of $\mathrm{C}$ from maturity level 0 to level 5 and yields 3.49. Therefore, dividing the value of $\mathrm{C}$ by the total number of $\mathrm{C}$ obtains 0.19 for maturity level 0 . The Contribution column is the result of multiplying the maturity level (ML) with the Normalize Contribution Value (D), where at maturity level 0 , the value is 0.00 . The final result of the maturity level, the sum of the contribution of maturity level 0 to maturity level 5, is 2.51 . In the DS4 IT process, six respondents produce different maturity levels, presented as follows: 
Table 6. The Average Value of the DS4 IT Process Maturity Level

\begin{tabular}{cc}
\hline Respondent & Maturity Level \\
\hline 1 & 2.26 \\
2 & 2.01 \\
3 & 2.35 \\
4 & 3.14 \\
5 & 2.29 \\
6 & 2.51 \\
Average $\left(\sum\right.$ ML/6) & $\mathbf{2 . 4 3}$ \\
\hline
\end{tabular}

Table 6 shows the maturity level of each respondent, where the average of the six respondents was sought to obtain the final result of the maturity level. The maturity level of the AI4 IT process is 2.43 , thus being at level 2 (repeatable but intuitive).

\subsection{Discussion}

The maturity data of the AI3 IT process at KOMINFO Bantul is at level 3. It indicates that KOMINFO Bantul has carried out maintenance on infrastructure in maximizing the contribution of information technology to achieve the desired goals. It has carried out a collaborative process with providers, but there has been no procedures or guidelines for cooperating correctly and adequately. In carrying out maintenance on each of its infrastructures, KOMINFO Bantul has followed the schedule set. Nevertheless, there was no coordination with the service provider. Furthermore, it has implemented the e-Health application [9], [10] at Puskesmas Bantul I, Bantul II, Banguntapan I, Banguntapan II, and Jetis I.

The things that support this condition include:

a) Critical Success Factor (CSF) survey in the AI3 IT process

Based on the CSF survey, KOMINFO Bantul has improved every component of the out of date IT infrastructure.

b) Key Performance Indica tor (KPI) survey in the AI3 IT process

Based on the KPI survey of the KOMINFO Bantul, the percentage of infrastructure use not following standards or has expired was around $20 \%$. Accordingly, those following the standards reached $80 \%$.

\section{Conclusions}

This research measured the maturity level of the IT processes based on the RACI model using the COBIT framework at KOMINFO Bantul. The results in the form of the current information technology governance conditions are as follows:

1. Processing the maturity level questionnaire, the AI3 IT process obtained a total value of 2.64 out of 5 , meaning that KOMINFO Bantul has implemented information technology governance at level 3 (defined process). Recommendations have been given to improve information technology governance to level 4 (managed and measurable).

2. The AI4 IT process obtained a total value of 2.73 out of 5, indicating that KOMINFO Bantul has implemented information technology governance at level 3 (defined process). The recommendations are intended to improve information technology governance to level 4 (managed and measurable).

3. The DS4 IT process obtained a total value of 2.43 out of 5, implying that KOMINFO Bantul has implemented information technology governance at level 2 (Repeatable but intuitive). Recommendations are given to improve information technology governance to level 3 (defined process). 


\section{References}

[1] M. Eremia, L. Toma, and M. Sanduleac, "The Smart City Concept in the 21st Century," Procedia Engineering, vol. 181, pp. 12-19, 2017, doi: 10.1016/j.proeng.2017.02.357.

[2] M. T. R. Farikhah, "Implementation of Smart Governance Concept Policy in Bantul Regency," JIPN, vol. 18, no. 2 , p. 129, Apr. 2020, doi: 10.35967/jipn.v18i2.7809.

[3] H. Nugroho and S. F. S. Gumilang, "Recommendations for Improving Data Management Process in Government of Bandung Regency using COBIT 4.1 Framework," in Proceedings of the 2020 9th International Conference on Software and Computer Applications, New York, NY, USA, Feb. 2020, pp. 57-61, doi: 10.1145/3384544.3384588.

[4] M. Yasin, A. A. Arman, I. J. M. Edward, and W. Shalannanda, "Designing Information Security Governance Recommendations and Roadmap Using COBIT 2019 Framework and ISO 27001:2013 (Case Study Ditreskrimsus Polda XYZ)," in 2020 14th International Conference on Telecommunication Systems, Services, and Applications (TSSA, Nov. 2020, pp. 1-5, doi: 10.1109/TSSA51342.2020.9310875.

[5] B. Shojaie, H. Federrath, and I. Saberi, "Evaluating the Effectiveness of ISO 27001: 2013 Based on Annex A," in 2014 Ninth International Conference on Availability, Reliability and Security, Sep. 2014, pp. 259-264, doi: 10.1109/ARES.2014.41.

[6] R. Y. Susanti and Y. G. Sucahyo, "Information technology governance evaluation and processes improvement prioritization based on COBIT 5 framework at secretariat general of the Indonesian house of representatives," in 2016 4th International Conference on Information and Communication Technology (ICoICT), May 2016, pp. 1-6, doi: 10.1109/ICoICT.2016.7571906.

[7] IT Governance Institute, Ed., COBIT 4.1: framework, control objectives, management guidelines, maturity models. Rolling Meadows, IL: IT Governance Institute, 2007.

[8] A. Pederiva, "The COBIT Maturity Model in a Vendor Evaluation Case," vol. 3, p. 4, 2003.

[9] Asroni, L. F. Hamdi, S. Wardaningsih, and W. A. Puspitosari, "E-emsy Development in the Implementation of Psychiatric Emergency Training for Nurses and Doctors,” Jan. 2021, pp. 590-603, doi: 10.2991/ahsr.k.210115.113.

[10] H. W. Utomo, "Evaluasi Sistem Informasi Kesehatan Terpadu e-Health Dengan Hot Fit Model Di Puskesmas Wilayah Kerja Dinas Kesehatan Kabupaten Bantul [Evaluation of the e-Health Integrated Health Information System with Hot Fit Models in the Community Health Center in the Bantul District Health Office]," other, Faculty of Public Health, 2011. 